Jurnal Studi Diplomasi dan Keamanan, Volume 13, No. 1, Januari 2021

\title{
PENGARUH TREN ENVIRONMENTALISME DALAM PEMASARAN PRODUK LUSH CORPORATION
}

\author{
Faradina Tshania Laily \\ Jurusan Hubungan Internasional \\ Fakultas Ilmu Sosial dan Politik \\ Universitas Pembangunan "Veteran" Jawa Timur \\ Email : faradina.tshanialaily@gmail.com
}

\begin{abstract}
ABSTRAK
Akibat glorifikasi dari environmentalisme menyebabkan isu terkait environmentalisme menjadi hal yang mainstream dan layak untuk diikuti oleh seluruh kalangan masyarakat. Karena maraknya tren tersebut memunculkan perubahan dalam pasar ekonomi sebagai respon dari munculnya tren baru. Hal tersebut juga terjadi pada Lush Corporation yang dalam studi hubungan internasional merupakan salah satu aktor multinational corporation (MNC) dan merupakan salah satu brand produk gaya hidup yang muncul serta dekat dengan isu-isu terkait kelingkungan tersebut. Tujuan dari jurnal penelitian ini adalah untuk mengetahui alasan mengapa tren environmentalisme dapat mempengaruhi pola produksi dan distribusi Lush Corporation dengan menggunakan metode penelitian kualitatif eksplanatif serta menggunakan pemaparan data sekunder sebagai data pendukung jurnal penelitian. Untuk menganalisis hal tersebut penulis menggunakan teori stakeholder dengan harapan menemukan temuan bahwa pemahaman masyarakat terhadap isu environmentalisme yang terstruktur dan tumbuh dalam masyarakat merupakan faktor kunci dari bagaimana tren pasar serta Lush Corporation mengubah haluan bisnisnya menjadi lebih ramah lingkungan dan ikut menerapkan etika-etika kelingkungan dalam kegiatan produksi dan distribusinya.
\end{abstract}

Kata Kunci : Environmentalisme, MNCs, Lush Corp., Stakeholder Theory, environmental friendly

\section{ABSTRACT}

Glorification of environmentalism issues caused any of environmentalism related issues become a mainstream topic and deserve to be a followed issues on society. Caused by the booming trend of environmentalism triggered a change in the economic market as a response of a new trend. That changing pattern also happened on Lush Corp that defined as multinational corporation (MNC) on internastional relation study and also as one of a lifestyle product brand that was born and close to the environmentalism issues. The research purpose of this paper is to know the reason why environmentalism trends can influence the production and distribution pattern of Lush Corp. This paper uses qualitative-explanation research methods with secondary data as supporting data. For analyzing the topic, author using stakeholder theory to expect findings that society comprehension towards environmentalism issues that is structured and grow on society is one of a key factor of how market (also Lush Corp) change it's business ethics to become more environmentally friendly and adjust the environmental ethics on production and distribution process.

Key words : Environmentalism, MNCs, Lush Corp., Stakeholder Theory, Environmental friendly 
Tren environmentalisme mulai memberikan pengaruh pada kegiatan bisnis internasional dengan membentuk arah dan selera konsumen sehingga secara tidak langsung juga mempengaruhi bagaimana tren dalam pasar yang berkonsekuensi mempengaruhi bagaimana perusahaan melakukan kegiatan produksi dan pemasaran produknya. Terutama dalam lingkup yang dilakukan oleh Multinational Companyatau perusahaan multinasional (kemudian akan disingkat menjadi MNCs) sebagai aktor dalam kegiatan produksi dan pemasaran kegiatan ekonomi internasional. Dampak dari tren environmentalisme yang paling tampak dan marak ditemui ada pada produk-produk gaya hidup. Perusahaan berlomba-lomba melakukan berbagai macam perubahan dan inovasi untuk mengikuti selera pasar sehingga tidak kehilangan pasar produknya dalam pasar internasional. Seperti muncul dan berkembangnya brand-brand dengan label eco-friendly seperti The Body Shop, Toms shoes, Burt's Bee, Patagonia, Revolve, Lush yang kemudian seiring dengan laju globalisasi yang membawa tren environmentalisme tersebut maka semakin banyak pula brand-brand yang muncul dengan konsep produksi eco-friendly. Tetapi terdapat juga banyak pro dan kontra dari perubahan yang muncul karena pada dasarnya kegiatan konsumsi yang menjadi tujuan utama suatu perusahaan sangat bertolak belakang dengan konsep environmentalisme yang menekan segala bentuk konsumsi baik karena limbah yang dihasilkan maupun sumber daya yang digunakan dalam kegiatan produksi.

Semakin maraknya tren environmentalisme yang berkembang beberapa tahun belakangan ini memiliki dampak yang besar dalam perubahan pola pikir masyarakat yang secara tidak langsung juga berdampak pada selera konsumsi pasar. Hal tersebut didukung dengan banyaknya peristiwa perubahan iklim yang kemudian direspon oleh PBB dengan diresmikannya perjanjian Kyoto pada 2005 dan diteruskan dengan Paris Agreement pada 2016 yang membahas hal-hal terkait upaya pengurangan emisi gas karbon yang merupakan penyebab terjadinya perubahan iklim. Tren enviromentalisme juga didukung semakin berkembangnya perkumpulan, gerakan hingga organisasi yang "membela" alam atau menjadi garda depan dalam menyelamatkan dan menjaga alam dari kerusakan untuk "memperlambat" dan mencegah perubahan iklim agar tidak menjadi semakin buruk, seperti Greenpeace dan World Wide Fund for Nature (WWF). Karena hal tersebut, banyak perusahaan industri yang mulai aktif menjalankan peran sebagai penjaga lingkungan untuk mengurangi limbah/polusi yang dihasilkannya sebagai bentuk respon terhadap tekanan yang diberikan oleh konsumen, bussiness-to-bussiness, hingga kebijakan yang ditetapkan oleh negara dimana perusahaan industri tersebut berada.

Salah satu contoh dari bagaimana tren environmentalisme yang terjadi di Amerika Serikat dipaparkan oleh (Elliott 2013) yang membahas bahwa minat konsumen Amerika Serikat terhadap produk "environmental friendly" pertama kali muncul bersamaan dengan munculnya kesadaran terhadap lingkungan hidup pada 
periode tahun 1960 dan 1970-an. Hal ini kemudian diikuti dengan masuknya brand produk yang mengklaim "green product"seperti Burt's Bees dan The Body Shop pada sekitar tahun 1980-an di pasar Amerika Serikat, diikuti dengan masuknya brand Lush di pasar Amerika Serikat pada tahun 1996 sebagai salah satu brand hijau yang populer. Periode 1980-an hingga memasuki awal tahun 1990 menjadi puncak dari pasar green product di Amerika Serikat yang mencapai angka 10\% dari jenis barang rumah tangga (produk gaya hidup). Ketertarikan pasar pada green product yang mulai mereda karena perkembangan dan pertumbuhan yang lambat serta stabil, kembali naik pada awal tahun 2000an, hal tersebut seiringan dengan munculnya kesadaran yang lebih tinggi tentang penemuan fakta bahwa perubahan iklim terjadi semakin cepat pada bumi sehingga konsumen di Amerika Serikat mulai kembali pada pasar green product bahkan mengalami perkembangan yang lebih cepat dan signifikan daripada sebelumnya. (Elliott 2013)

Isu environmentalisme yang pertama kali menyentuh sektor industri ekonomi sekitar tahun 1980-an menjadi salah satu alasan lahirnya Lush Corp pada tahun 1995. Dengan mengedepankan produksi kosmetik buatan tangan yang dipasarkan secara langsung karena menggunakan bahan-bahan alami tanpa menggunakan bahan kimia berbahaya sehingga limbah dari produksi hingga penggunaan produk tersebut lebih ramah lingkungan. Seperti yang telah dipaparkan dalam jurnal Elliot diatas, dapat dilihat bahwa kenaikan kembali konsumsi green product terjadi pada tahun 2000an, sehingga penulis akan menggunakan waktu antara tahun 2017 hingga 2018. Pengambilan jangkauan waktu penelitian pada tahun 2017 tersebut sesuai dengan rumusan masalah yang diangkat yaitu mengapa tren environmentalisme dapat mengubah pola produksi dan distribusi (marketing) Lush Corp; tahun 2017 merupakan tahun pertama terjadinya perubahan kegiatan distribusi pada Lush Corp dengan mengenalkan inovasi naked product atau produk tanpa kemasan. Pengambilan topik terkait isu environmentalisme dalam kegiatan industri MNCs oleh penulis ditujukan untuk lebih mengenalkan pengaruh tren yang muncul dan berkembang dalam lingkup masyarakat internasional terhadap pola dan arus pasar perdagangan internasional. Tren environmentalisme, sama dengan tren-tren sebelumnya yang berkembang di dalam masyarakat internasional, merupakan salah satu bentuk adanya komunikasi internasional dalam masyarakat sehingga dapat tercipta suatu tren terkait isu environmentalisme tersebut. Selain itu, dalam pembentukannya terdapat berbagai macam aktor yang ikut serta membawa tren environmentalisme ini ke permukaan sehingga lingkup penyebaran tren tersebut tidak eksklusif pada lingkup masyarakat tertentu tetapi juga dapat diikuti oleh masyarakat awam. Aktor yang berperan dalam penyebaran tren environmetalisme sendiri dimulai dari tokoh individu seperti Mark Ruffalo sebagai salah satu aktivis lingkungan yang banyak mengangkat isu pengaruh penggunaan minyak dan gas industri terhadap lingkungan, kemudian organisasi non-pemerintah internasional seperti Greenpeace, yang juga didukung dengan organisasi internasional perserikatan bangsa-bangsa (PBB) dalam United Nation 
Environment Programme (UNEP). Beragamnya aktor yang berperan dalam penyebaran tren environmetalisme tersebut menyebabkan cepatnya laju pengikut tren tersebut dalam masyarakat internasional.

\section{TINJAUAN PUSTAKA}

Untuk pemahaman lebih lanjut serta memberikan gambaran dasar untuk menjawab rumusan masalah, penulis melakukan tinjauan pustaka pada beberapa jurnal yang memuat tentang isu environmentalisme dan MNCs. Jurnal pertama dengan judul Corporate Environmentalism: Antecedents and Influence of Industry Type ditulis oleh (S. B. Banerjee 2003) mengangkat rumusan masalah tentang bagaimana perusahaan bisnis mengelola hubungan kegiatan perusahaan dengan natural environment. Dengan menggunakan teori stakeholder, green politics serta konsep tentang politik-ekonomi, jurnal ini menggunakan sampling frame dan mailing procedure untuk pengumpulan data. Kesimpulan yang diangkat oleh penulis jurnal tersebut bahwa perhatian publik terhadap isu lingkungan dapat mempengaruhi strategi marketing perusahaan industri serta kebijakan-kebijakan tentang lingkungan juga memiliki pengaruh signifikan terhadap strategi perusahaan yang memiliki kebijakan hijau dalam kegiatan industrinya. Dapat dilihat bahwa peran stakeholder eksternal dari MNCs memiliki peran dalam mengubah haluan MNCs tersebut.

Hampir sama dengan jurnal sebelumnya yang menekankan peran stakeholder dalam pengambilan keputusan dari MNCs, jurnal yang ditulis oleh (Lang 2007) mengangkat rumusan masalah tentang bagaimana pemahaman environtalisme mempengaruhi perusahaan multinasional dalam bisnis internasional dengan menggunakan konsep bisnis internasional terkait foreign direct investment (FDI) dan perusahaan multinasional sebagai aktor pelaku kegiatan bisnis internasional serta kajian tentang environmentalisme. Jurnal yang berjudul Environmentalism and the multinational corporation: viewpoint:part II ini tidak menggunakan metode penelitian tertentu serta tidak memaparkan data untuk melengkapi jurnal penelitian tersebut, penulis lebih terfokus dalam penjelasan-penjelasan deskriptif. Kesimpulan yang ditawarkan dalam jurnal ini adalah kekuatan (power) sebagai kapabilitas didefinisikan sebagai hubungan antara kepemilikan dan kontrol atas perusahan multinasional, sedangkan kekuatan sebagai pengaruh diartikan sebagai proses bargaining antara perusahaan multinasional dengan stakeholdernya (pembuat kebijakan environmentalisme di host country) sementara kompetisi global diartikan sebagai nilai dari perusahaan multinasional di dunia bisnis internasional. 
Dalam jurnal yang ditulis oleh (Rhodes 2014) dengan judul $A$ Framework for Stakeholder Engagement and Sustainable Development in MNCs diangkat rumusan masalah tentang bagaimana MNCs mengembangkan serta meningkatkan efektifan keterkaitan atau hubungan dengan stakeholder dan pembangunan berkelanjutan (sustainable development). Dalam jurnal tersebut penulis menggunakan beberapa teori meliputi stakeholder theory, resource dependency theory, stakeholder engagement concept, company social responsibility (CSR) concept, serta sustainable development concept. Kesimpulan yang dijabarkan dalam jurnal ini adalah keterkaitan antar stakeholder merupakan mediator kunci antara stakeholder (internal maupun eksternal dari MNCs) dengan hasil atau pencapaian dari MNCs tersebut (CSR, shared value dan pembangunan berkelanjutan). Serta untuk mencapai keefektifan dari keterkaitan antar stakeholder diperlukan adanya integrasi dan keselarasan antara faktor internal MNCs seperti kemampuan manusia (bakat), teknologi, finansial, leadership, struktur organisasi serta budaya dalam MNCs tersebut dengan faktor eksternal dari MNCs itu sendiri seperti faktor sosial, politik, budaya, lingkungan, external stakeholder(konsumen), dan NGOs.

Dapat dilihat dari tinjauan pustaka diatas terdapat beberapa kesamaan fokus penelitian yaitu peran dan pengaruh dari stakeholder (dalam hal ini konsumen dan investor) bagi MNCs dalam isu environmentalisme di bidang perdagangan internasional. Untuk memperbarui penelitian tentang pengaruh environmentalisme terhadap MNCs penulis menyimpulkan bahwa hubungan antara marketplace yang terpengaruh oleh tren environmentalisme dengan MNCs dalam proses produksi dan distribusinya (marketing) sebagai isu yang belum dianalisis dari kumpulan jurnal yang telah dijadikan sebagai tinjauan pustaka diatas. Hal tersebut yang menjadi fokus artikel ini dengan menggunakan studi kasus Lush Corporation sebagai salah satu MNCs yang erat dengan pemasaran environmentalisme-nya sebagai fokus aktor dalam penelitian ini. Selain itu, artikel ini juga menjadi pembaharuan dari jurnal-jurnal diatas yang menggunakan jangkauan waktu penelitian dari tahun 2003 hingga tahun 2014. Artikel ini membahas jangkauan waktu 2016 hingga 2018 yang juga menjadi tahun puncak dari tren environmentalisme dengan munculnya banyak penemuan produk alternatif yang lebih ramah lingkungan. Dalam hal ini penulis mengangkat rumusan mengapa tren environmentalisme dapat mengubah pola produksi dan distribusi (marketing) dari Lush Corporation.

\section{KERANGKA PEMIKIRAN}


Berangkat dari tinjauan pustaka yang telah dijelaskan diatas bahwa terdapat beberapa faktor penting yang tentang hubungan antara tren environmentalisme yang dapat mempengaruhi strategi marketing MNCs, yaitu perhatian publik serta kekuatan influence tentang isu, serta respon MNCs terhadap isu dan tren environmentalisme tersebut. Tujuan dari penulisan jurnal penelitian ini adalah mengetahui mengapa tren environmentalisme dapat mengubah pola produksi dan distribusi (marketing) Lush Corp berangkat dari ditemukannya research gap dari jurnal-jurnal sebelumnya yaitu tentang hubungan antara marketplace yang dipengaruhi tren environmentalisme dengan MNCs dalam proses produksi dan distribusi (marketing). Artikel jurnal ini menggunakan studi kasus Lush Corp dengan jangkauan waktu penelitian dari tahun 2016 hingga tahun 2018. Hampir sama dengan jurnal-jurnal sebelumnya yang menggunakan teori-teori tentang bagaimana stakeholder mempengaruhi MNCs, dalam jurnal ini juga akan menggunakan teori serupa untuk mengkaji lebih dalam tentang kausalitas kedua variabel yang menjadi fokus utama yaitu tren environmentalisme dan MNCs. Berikut merupakan pemetaan variabel dan teori yang akan digunakan dalam junal ini:

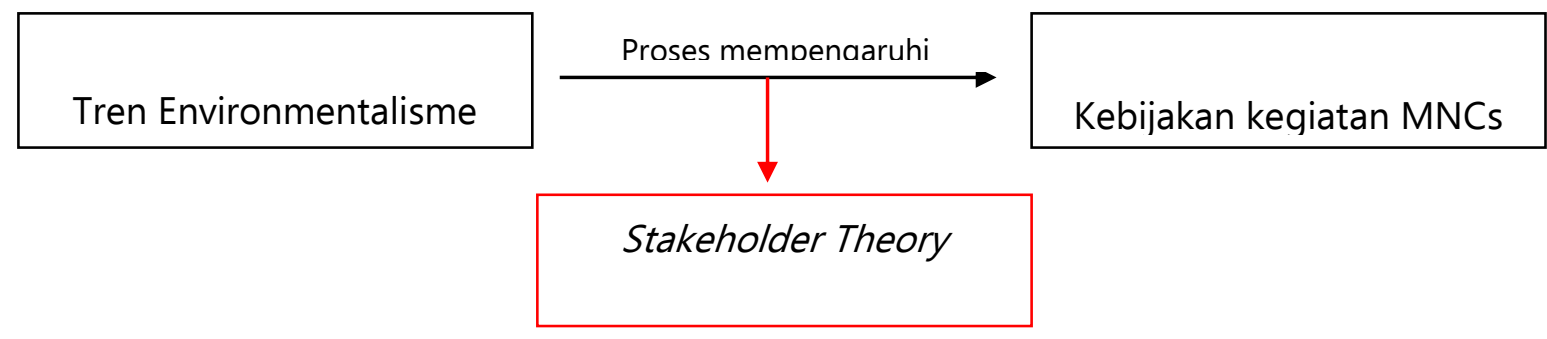

Seperti yang telah dipaparkan dalam diagram di diatas, penulis akan menggunakan stakeholder theory dalam kajian studi bisnis internasional untuk mengkaji fenomena tren environmentalisme yang muncul akibat konstruksi internasional terkait isu environmentalisme. Menurut Freeman (2015) teori stakeholder menjelaskan hubungan dari stakeholder (investor, konsumen) dengan perusahaan, dimana suatu perusahaan tidak dapat mengabaikan apa yang menjadi perhatian dari para stakeholder. Teori ini menjelaskan bahwa adanya proses akomodasi ide hingga pengaruh dari pihak stakeholder terhadap perusahaan sebagai pelaku bisnis. Tetapi teori ini juga menjelaskan bahwa tidak dapat terjadi trade-off antar kepentingan stakeholder karena teori ini menjelaskan hubungan antara stakeholder dengan perusahaan bukan antar stakeholder. Salah satu indikator penting dalam teori ini adalah adanya transnational advocate network yang merupakan kelompok yang terdiri dari konsumen yang memiliki kepentingan sama sehingga dapat menuntut atau mempengaruhi MNCs karena negara tidak memiliki power untuk mengontrol MNCs yang ada di dalamnya. 
Sama dengan jurnal-jurnal yang digunakan penulis sebagai tinjauan pustaka bahwa stakeholder memiliki peran penting dalam siklus pasar sehingga juga secara tidak langsung akan mempengaruhi MNCs.

\section{METODE PENELITIAN}

Metode penelitian yang digunakan oleh penulis untuk jurnal penelitian ini adalah metode penelitian kualitatif eksplanatif. Penggunaan metode penelitian kualitatif eksplanatif memiliki tujuan untuk menjelaskan keterkaitan atau hubungan antara tren environmentalisme dengan Lush Corp sebagai aktor ekonomi bisnis internasional (MNCs) dalam proses produksi dan distribusinya. Data yang digunakan adalah data sekunder dari studi kasus yang berkaitan dengan Lush Corp baik yang dimuat di media berita, website bisnis, website resmi dari Lush Corp hingga jurnal-jurnal sebelumnya yang pernah membahas tentang fokus penelitian serupa dan diproses dengan analisis wacana. Data yang digunakan meliputi perkembangan tren environmentalisme dalam dunia ekonomi dengan pemaparan perusahaan-perusahaan yang muncul dalam pasar internasional yang mengusung eco-friendly, analisis etika bisnis hijau yang diterapkan oleh Lush Corp dalam visi dan misi perusahaan, analisis pasar produk Lush Corp dalam bentuk grafik persaingan bisnis perusahaan-perusahaan serupa, grafik pencapaian penjualan produk, serta rating kepuasan konsumen pada tahun 2017-2018.

\section{PEMBAHASAN}

Seperti yang telah dijelaskan dalam kerangka berpikir, penulis akan menganalisis lebih lanjut mengapa tren environmentalisme dapat mengubah pola produksi dan distribusi Lush Corporation menggunakan teori stakeholder yang dikemukakan oleh (Freeman, 2015) yaitu mengenai hubungan pihak stakeholder (dalam hal ini didefinisikan sebagai konsumen) dengan pihak perusahaan (dalam hal ini didefinisikan sebagai Lush Corporation atau penyedia pasar). Teori stakeholder menitikberatkan pada hubungan ketergantungan antar kedua pihak sehingga pihak perusahaan tidak dapat mengabaikan kritik dan saran yang datang dari pihak konsumen sebagai usaha mempertahankan kepercayaan konsumen kepada perusahaan sebab konsumen merupakan penentu keberlanjutan atau eksistensi suatu perusahaan tersebut. Hubungan ketergantungan antara pihak konsumen dan perusahaan tersebut saling mempengaruhi bagaiamana jalannya kegiatan transaksi dalam pasar. Apabila perusahaan dapat membaca minat konsumen dengan baik maka pasar dari perusahaan tersebut dapat terus berjalan dan terjadi perputaran ekonomi, tetapi perusahaan juga bergantung dengan loyalitas konsumen terhadap produk-produk perusahaan tersebut sehingga upaya dari perusahaan untuk 'mendengar' konsumen juga penting untuk mempertahankan 
perputaran ekonomi pasar perusahaan tersebut. Dalam hal ini penulis juga melihat bagaimana konsumen juga dapat terkena pengaruh suatu tren tertentu sehingga juga ikut mempengaruhi selera beli konsumen terhadap produk-produk tertentu.

Variabel pertama dalam paper ini adalah tren environmentalisme yang nantinya menjadi faktor penyebab dari terjadinya perubahan dalam kegiatan produksi dan distribusi Lush Corporation. Tren enviromentalisme muncul dan terbentuk dari dalam masyarakat yang juga merupakan aktor pasar baik sebagai pelaku kegiatan konsumen maupun pelaku kegaitan produksi hingga distribusi. Tetapi pemahaman environmentalisme yang muncul dalam masyarakat tidak semata-mata dapat menjadi tren yang diikuti oleh banyak masyarakat global. Terdapat aktor lain yang menjadi agen dari berkembangnya pemahaman environmentalisme tersebut yaitu Non-Governmental Organization (NGOs) atau organisasi non pemerintah (selanjutnya akan disingkat menjadi NGO). NGO sendiri memiliki eksistensi tersendiri di dalam masyarakat sebagai salah satu aktor yang memiliki pengaruh baik dalam hal merubah pola pikir masyarakat hingga dapat ikut serta dalam kegiatan-kegiatan yang bersifat hard politics seperti dalam hal kegiatan ekonomi. Banyak perusahaan pelaku ekonomi yang menggandeng NGO tertentu untuk mencakup pasar yang lebih besar dengan target konsumen yang sesuai sehingga loyalitas konsumen dapat ditingkatkan oleh pihak perusahaan.

Berkembangnya NGO berbasis lingkungan merupakan salah satu bukti isu environmentalisme telah berkembang menjadi salah satu isu yang sangat diperhitungkan dalam dunia internasional. Begitu pula dengan tren-tren berbasis lingkungan yang muncul dan diikuti oleh masyarakat, seperti \#zeroplastics yang merupakan salah satu tren yang dipopulerkan oleh Greenpeace sebagai salah satu NGO berbasis lingkungan yang memiliki pengaruh besar dalam muncul dan berkembangnya tren terkait sustainability dan kesadaran lingkungan. Tren \#zeroplastics muncul pada tahun 2019 sebagai respon terhadap menumpuknya sampah plastik di laut yang diestimasikan sebanyak 12 juta ton serta sebagai respon dari gagalnya sistem daur ulang plastik yang mengakibatkan 90\% dari sampah plastik mencemari lingkungan. Tren \#zeroplastics dibuat untuk mempromosikan reduce dan reuse produk berkemasan plastik sehingga diharapkan dapat menekan perkembangan sampah plastik (Poggenpohl 2019). Dalam contoh kasus tersebut dapat dilihat bahwa NGO merupakan salah satu indikator dalam menciptakan tren environmentalisme dalam masyarakat internasional yang disertai dengan peran media sebagai perantara penyampaian kampanye tren environmentalisme yang diciptakan oleh NGO tersebut.

Dalam perkembangannya NGO berbasis lingkungan telah berkembang pesat di dunia internasional mulai dari NGO yang beroperasi dalam lingkup internasional hingga secara lokal dalam negara. Seperti yang 
dimuat dalam artikel sustainability degree terdapat 14 NGOs dengan lingkup internasional maupun lokal (dalam negara) yang sangat berpengaruh dalam menciptakan, mengembangkan dan mendukung sustainability baik dalam lingkup masyarakat hingga pelaku ekonomi: Ceres, Conservation International (CI); Doctors Without Borders; Food and Water Watch; Greenpeace; Haifer International; Natural Resources Defence Council (NRDC); The Nature Conservancy (TNC); Ocean Concervacy; Oxfam; Sierra Club; Slow Food International; WorldRecources Institute; World Wildlife Fund (WWF). NGO tersebut merupakan pemimpin dalam menciptakan tren environmentalisme yang dapat mempengaruhi masyarakat internasional dan membentuk kesadaran akan pentingnya sustainability demi kelestarian lingkungan. Dapat dikatakan bahwa tren environmentalisme dapat muncul akibat respon NGO berbasis lingkungan dalam menangkap isu lingkungan yang terjadi dan kemudian mengembangkan ide tersebut dalam bentuk kampanye, gerakan terjun langsung ke lapangan, dan seminar edukasi untuk meningkatkan kesadaran masyarakat internasional.

\section{Analisis Perubahan Kebijakan Produksi dan Distribusi Lush Corporation Terkait dengan Tren Environmentalisme}

Dalam (S. B. Banerjee 2003), menjelaskan penerapan teori stakeholder dengan melihat bagaimana suatu perusahaan mengubah haluan sistem produksi dan distribusinya menjadi lebih eco-friendly akibat beberapa faktor yaitu, munculnya perhatian publik terhadap isu environmentalisme, pengaruh pembuat regulasi dimana perusahaan tersebut berdiri, keunggulan dalam kompetisi bisnis dan komitmen top management. Jika dilihat melalui bagaimana NGOs mempengaruhi masyarakat dalam cara pandang terhadap pelestarian lingkungan, maka faktor perhatian publik menjadi salah satu alasan utama bagaimana perusahaan mengubah haluan produksi dan distribusinya, karena pada dasarnya masyarakat tersebut merupakan konsumen dari perusahaan yang juga menjadi pertimbangan dalam pengambilan keputusan perusahaan. Munculnya satu perusahaan dengan visi dan misi berbasis pelestarian lingkungan yang kemudian mendapatkan pasar walaupun kecil tetapi juga memiliki interaksi konsumen-perusahaan yang cukup intens menyerupai konsep red ocean strategy dimana pelaku ekonomi menciptakan pasar sendiri dengan intensitas kompetisi rendah. Tetapi karena isu pelestarian lingkungan sudah menjadi hal yang mainstream pasar green product menjadi lebih luas dengan persaingan yang lebih ketat, hal tersebut terbukti dengan semakin banyaknya perusahaan yang mulai menciptakan produk dengan label eco-friendly dengan maksud untuk menarik konsumen yang memiliki perhatian terhadap isu lingkungan tersebut. Seperti halnya The Body Shop, Toms shoes, Burt's Bee, Patagonia, Revolve dan Lush, label perusahaan eco-friendly tersebut dapat dilihat sebagai bentuk usaha menciptakan citra brand perusahaan sesuai dengan konsep pelestarian lingkungan 
dengan didukung rekam jejak yang baik melalui kegiatan Corporate Social Responsibility (CSR) ataupun kampanye-kampanye lingkungan yang dilakukan oleh perusahaan tersebut.

Dapat dilihat bahwa tren environmentalisme yang tumbuh dan berkembang dalam konsumen internasional dipengaruhi oleh peran NGOs dalam menciptakan dan mengenalkan tren untuk peduli dan melestarikan lingkungan. Kemudian muncul pertanyaan bagaimana tren environmentalisme tersebut dapat mempengaruhi perusahaan dalam mengambil kebijakan yang berbasis pada kepedulian isu lingkungan. Dalam artikel ini penulis menggunakan stakeholder theory untuk menghubungkan kedua variabel tersebut dalam hubungan kausalitas. Freeman,(2015) mendefinisikan stakeholder sebagai individu atau sekelompok individu yang dapat mempengaruhi atau dipengaruhi oleh pencapaian dari visi-misi perusahaan, dalam hal ini stakeholder dikelompokkan sebagai konsumen dan komunitas lokal, NGOs atau aktivis yang memiliki kemampuan untuk memobilisasi opini publik. Dalam paper ini penulis memfokuskan konsumen dan CEO Lush Corp sebagai stakeholder. Secara teknis stakeholder theory dalam kasus perusahaan yang memperhatikan isu lingkungan dapat diilustrasikan sebagai berikut:

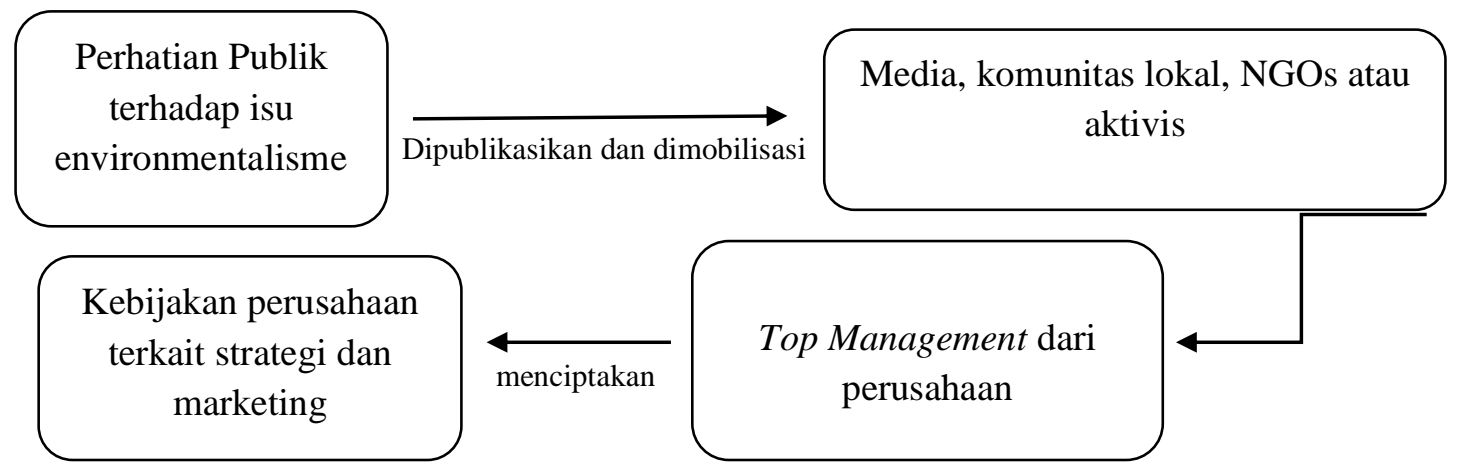

obilisasi

oleh media dapat mempengaruhi bagaimana perusahaan memandang kondisi pasar yang ada, sehingga munculnya perhatian publik terhadap isu environmentalisme dalam pasar internasional secara tidak langsung akan mempengaruhi permintaan konsumen terhadap produk-produk eco-friendly. Hal ini membuat top management (dapat diartikan sebagai board of Directors, chief executive officer (CEO)) mulai memperhitungkan peluang keuntungan dari kondisi pasar yang mulai didominasi dengan permintaan produk eco-friendly dan menciptakan strategi bisnis dan marketing baru untuk mendukung kegiatan produksi dan distribusi yang berbasis kepedulian terhadap lingkungan. Selanjutnya akan dipaparkan data-data yang mendukung penggunaan teori tersebut dan membuktikan adanya hubungan antara kedua variabel yang diangkat oleh penulis. 


\section{Perhatian publik (public concern)}

Dalam studi kasus Lush Corp, indikator perhatian publik terhadap isu environmentalisme dapat dilihat melalui adanya konsumen yang memperhatikan etika, visi misi, dan komitmen perusahaan untuk memproduksi produk $100 \%$ vegetarian, mengenalkan dan mempraktekkan ethical buying, cruelty-free atau tidak melakukan tes produk menggunakan hewan, freshest cosmetics online atau mendistribusikan produk baru-produksi meskipun melalui pembelian online; handmade atau buatan tangan dan menggunakan mesin produksi seminimal mungkin untuk mengurangi konsumsi energi; menekan production footprint dan naked product atau distribusi produk langsung tanpa kemasan. Dalam strategi bisnisnya, Lush Corp memprioritaskan interaksi dengan konsumen melalui berbagai macam media perantara. Mereka juka menerapkan prinsip "because the customers is always right" atau jika ditranslasikan "karena konsumen selalu benar". Di sisi lain, konsumen Lush juga terpengaruh dengan berkembangnya isu lingkungan melalui tren environmentalisme yang mengarahkan konsumsi produk masyarakat menjadi diet konsumsi produk. Menurut (S. B. Banerjee 2003) perhatian publik terhadap isu environmentalisme sendiri dapat mempengaruhi perusahaan dalam kegiatan produksi hingga distribusinya melalui dua cara yaitu (1) perusahaan memproduksi green product sebagai respon dari perhatian publik terdapap isu environmentalisme atau dengan kata lain perusahaan memenuhi kebutuhan atau permintaan publik terhadap produk yang ramah lingkungan, (2) perusahaan mengembagkan strategi environmentalisme atau strategi bisnis hijau untuk meraih konsumen yang memiliki perhatian terhadap isu environmentalisme tersebut sebagai target pasar baru perusahaan atau dengan kata lain perusahaan tersebut memperluas target pasar perusahaan untuk mencapai keuntungan lebih.

Dalam hal tersebut Lush merupakan jenis perusahaan yang merespon perhatian publik terhadap isu environmentalisme dengan cara pertama. Lush merespon perhatian konsumennya (yang juga terdapat faktor pendukung internal dari pihak Lush) untuk memperbarui dan menciptakan produk yang dapat diterima serta sesuai dengan tren yang ada di publik untuk melestarikan lingkungan. Dalam hal ini Lush Corp sangat menitik beratkan pada isu lingkungan terkait pengurangan penggunaan plastik sebagai kemasan sebagai usaha mengurangi sampah plastic di laur. Perhatian terhadap isu sampah plastik tersebut juga diperhatikan oleh CEO dari Lush Corp yang juga merupakan salah satu aktivis lingkungan sehingga proses penerapan kegiatan produksi yang menekan penggunaan plastik dalam Lush Corp dapat dengan mudah ter-realisasikan; selain karena pada dasarnya etika produksi dari Lush Corp sendiri juga menerapkan konsep eco-friendly. Selain merespon perhatian publik terhadap isu environmentalisme, Lush juga ikut merangkul dan menjembatani konsumennya kepada kegiatan yang berhubungan dengan pelestarian lingkungan, seperti beberapa 
campaign yang dilakukan oleh Lush dalam bidang pelestarian lingkungan mulai dari kegiatan CSR (corporate social responsibility) hingga bentuk kampanye yang dikemas dalam kegiatan distribusi atau pemasaran produknya. Salah satu contohnya adalah dengan dirilisnya salah satu produk Lush yaitu Charity Pot yang merupakan salah satu jenis produk yang digunakan Lush untuk membantu perbaikan dan pelestarian lingkungan melalui kerjasama dengan berbagai NGO dengan mendonasikan 100\% keuntungan dari penjualan produk tersebut (Lush, 2016). Pada tahun 2009 Lush merilis Jungle Charity Pot yang digunakan untuk mempromosikan pelestarian hutan hujan dan bekerjasama dengan Rainforest Foundation sebagai penerima donasi.

Berikut penulis melampirkan data keuntungan dari penjualan global produk Lush dari tahun 2014 hingga tahun 2018 sebagai data pendukung bagaimana perhatian publik mulai muncul dan berkembang setelah munculnya invoasi naked product sebagai respon Lush Corporation terkait isu sampah plastik sebagai salah satu isu yang diperhatikan oleh banyak publik baik dalam komunitas pencinta lingkungan maupun publik awam yang menjadi konsumen produk-produk Lush.

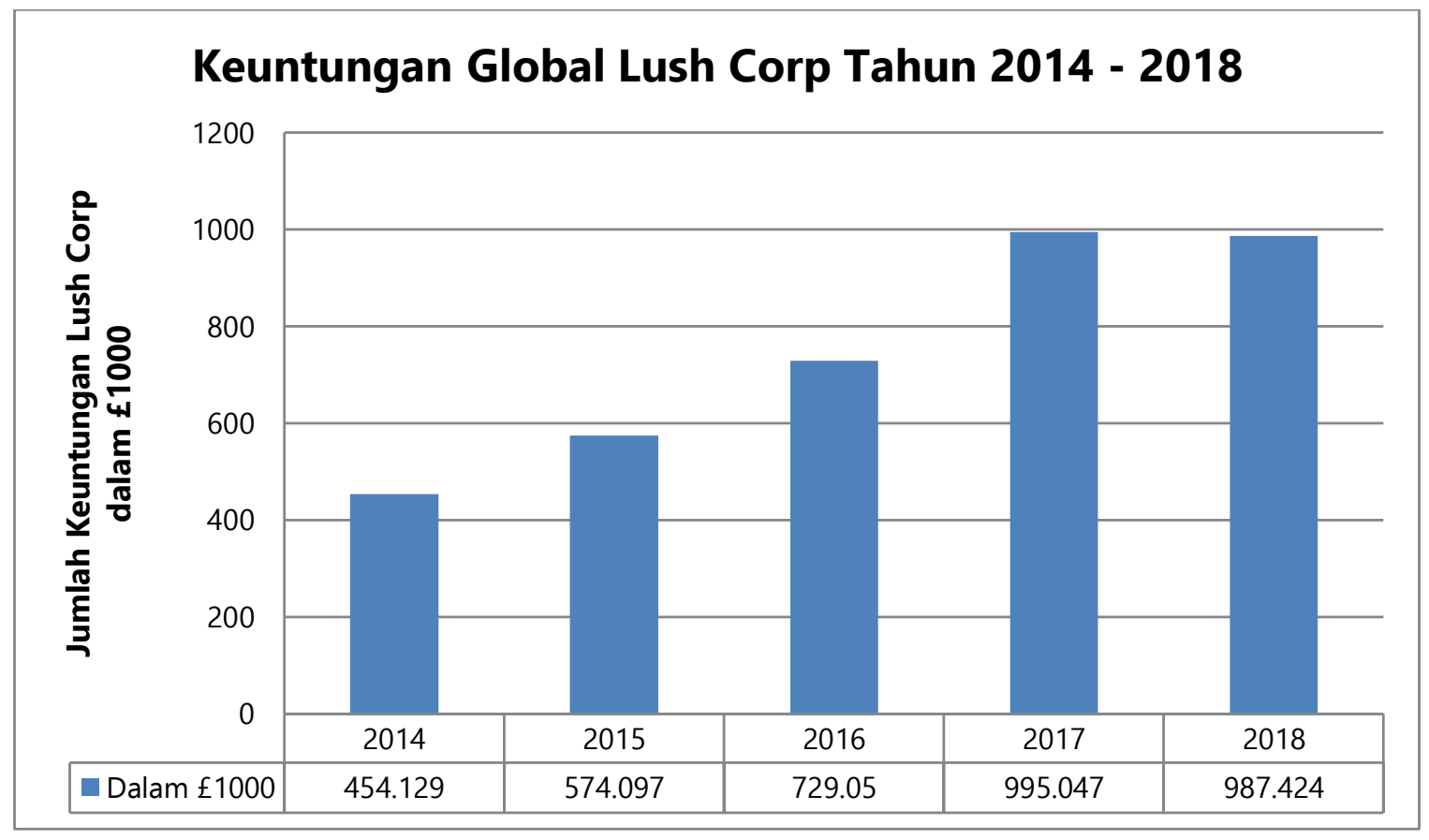

Grafik 1.2 Data Keuntungan Global Lush Corporation Tahun 2014-2018

\section{Sumber : statista.com}

Dapat dilihat bahwa terjadi peningkatan yang cukup tajam pada tahun 2017 tahun saat inovasi naked product diperkenalkan secara resmi oleh Lush Corporation sebagai respon dari tingginya volume sampah kemasan plastik yang mencemari lingkungan terutama ekosistem laut. Antara tahun 2014-2016, peningkatan penjualan 
tahunan Lush Corporation adalah 26\% dan 27\% namun pada tahun 2017 peningkatan penjualan naik ke angka 36.5 persen. Peningkatan keuntungan dari penjualan produk Lush pada tahun 2017 menunjukkan bahwa inovasi naked product berhasil mendapatkan perhatian publik para konsumen Lush yang memperhatikan isu terkait sampah kemasan plastik yang dapat menganggu ekosistem laut dalam usaha mengurangi konsumsi plastik bagi konsumen. Hal tersebut juga membawa konsekuensi positif lain bagi lush yaitu pengurangan biaya produksi Lush dari dihapusnya biaya produksi kemasan plastik. Biaya produksi tersebut kemudian dapat dialihkan pada inovasi atau pengembangan produk secara maksimal baik dalam hal bahan-bahan produk hingga penelitian laboratorium kimia untuk daya tahan produk, senyawa aroma yang aman untuk kulit dan lain sebagainya. Dikutip dari (Loeb 2017) peningkatan dari penjualan produk Lush pada tahun 2017 merupakan salah satu bentuk dari perkembangan informasi terkait isu environmentalisme yang beredar pada generasi Gen Z sebagai salah satu konsumen tertinggi dari Lush Corp tersebut. Dalam (Loeb 2017) juga dipaparkan bahwa $81 \%$ dari konsumen kegiatan ekonomi lifestyle lebih memilih perusahaan atau bran yang aktif dalam kegiatan charity terhadap isu kritis seperti perubahan iklim, kelaparan dan krisis air.

\section{Media, Komunitas Lokal, NGOs atau Aktivis}

Terdapat banyak variasi media komunikasi konsumen dengan Lush Corp. Salah satunya adalah live experience atau pengalaman langsung saat konsumen mengunjungi toko Lush untuk mengenal atau membeli produk Lush yang kemudian juga akan disambut dan diberikan penjelasan langsung oleh pegawai Lush tentang produk tersebut. Melalui live experience, Lush corp menggunakan pegawai sebagai front-liner untuk menyerap ide, saran hingga keluhan konsumen terhadap pengembangan dan produksi produk. sLush juga meluncurkan aplikasi gawai yaitu Lush Connect yang digunakan sebagai platform bagi konsumen, pegawai dan top management untuk saling berkomunikasi, mengutarakan ide, pengenalan produk baru serta mempromosikan kampanye-kampanye perlindungan lingkungan (Skins 2010). Untuk menganalisis lebih dalam bagaimana peran perhatian publik (terutama konsumen Lush) dalam kegiatan produksi dan distribusi produk Lush penulis melampirkan data kepuasan konsumen terhadap respon dan pelayanan baik secara langsung melalui toko maupun secara online. 


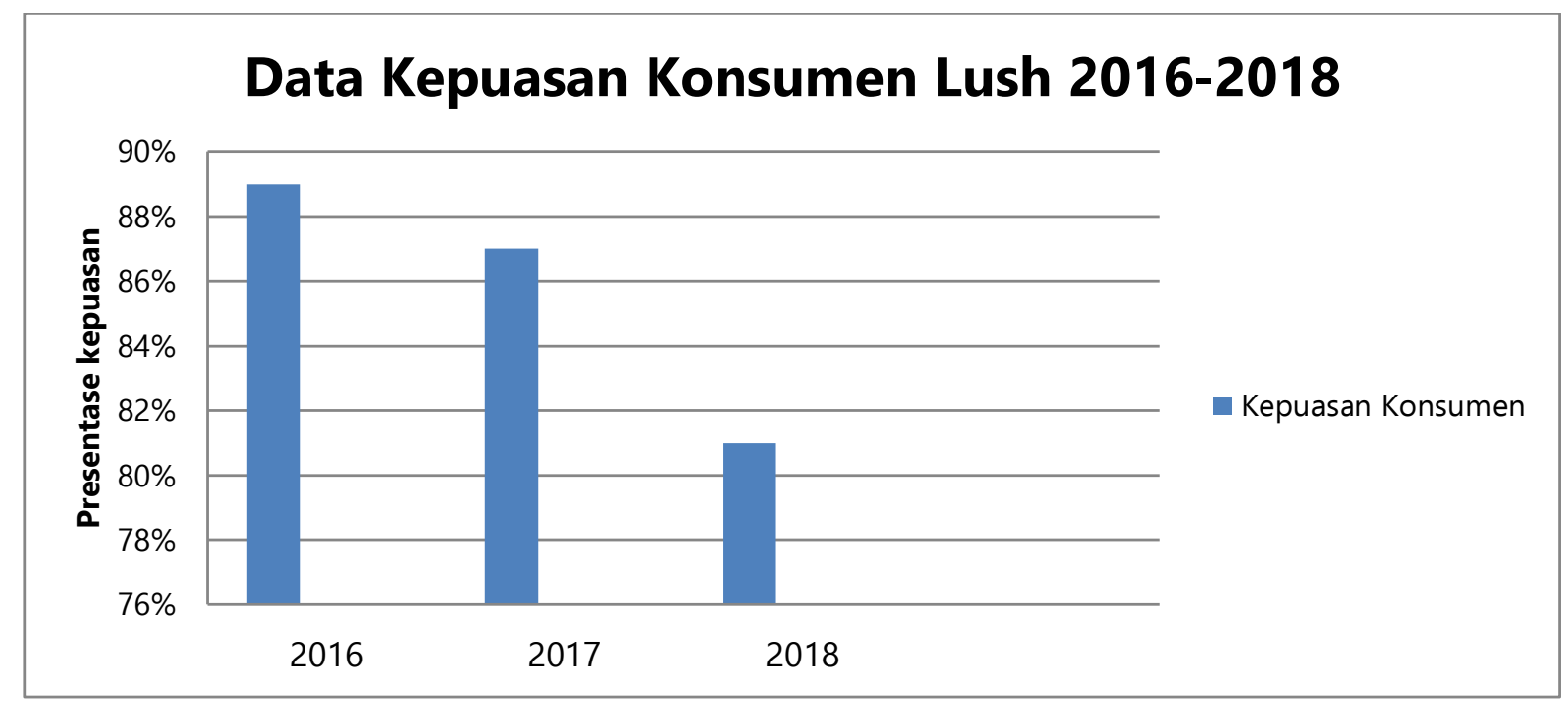

Grafik 1.1 Data Persentase Kepuasan Konsumen Lush 2016-2018

sumber: which.co.uk

Meskipun terlihat terjadi penurunan, Lush Corporation selalu menjadi perusahaan yang menduduki ranking 1 dalam hal kepuasan konsumen dalam respon dan pelayanan di Inggris dibandingkan dengan brand lainnya. Hal tersebut membuktikan bahwa komunikasi antara konsumen dan perusahaan berjalan dengan harmonis dan terdapat feedback yang dapat diperoleh oleh kedua pihak. Salah satu feedback yang muncul akibat komunikasi konsumen dengan Lush adalah inovasi naked product pada tahun 2017 seperti yang dipaparkan dalam (Shepherd 2017) sebagai respon dari munculnya kesadaran akan sampah kemasan produk kosmetik yang merupakan salah satu penyumbang dari pencemaran laut. plastik dari komunitas konsumen Lush yang juga didukung dengan muncul dan berkembangnya tren kampanye \#zeroplastic sebagai bentuk totalitas dan dedikasi perusahaan Lush atas visi dan misi seperti yang telah dijelaskan sebelumnya.

Seperti yang telah dijelaskan dalam poin perhatian publik, peran NGOs dalam bidang pelestarian lingkungan sangat besar bagi pembentukan arus ekonomi produk ramah lingkungan, baik sebagai trendsetter bagi kegiatan pelestarian lingkungan hingga sebagai pencipta pola pikir environmentalisme dalam masyarakat sehingga menciptakan tren environmentalisme tersebut. NGOs juga berperan sebagai aktor yang membantu perusahaan untuk mencapai visi misi perusahaan yang berkaitan dengan pelestarian lingkungan. NGO juga menjadi pihak perantara antara perusahaan dengan lingkungan alam, dalam hal ini Lush sebagai perusahaan yang menyediakan dana untuk pelestarian, penjagaan hingga perbaikan lingkungan yang berasal dari keuntungan penjualan produk dan dana tersebut diberikan kepada NGO yang dalam bidang pelestarian alam. Lush juga menjadi pihak perantara antara konsumen dengan lingkungan alam, 
karena pada dasarnya konsumen Lush melakukan konsumsi produk yang dilabeli charity pot product sebagai bentuk donasi untuk lingkungan melalui pembelian produk Lush.

\section{Top Management}

Menurut (S. B. Banerjee 2003) keterlibatan Top management yang dalam hal ini dapat dikategorikan sebagai board of Directors (BOD) atau chief executive officer (CEO) dalam isu environmentalisme lebih telihat apabila perushaan tersebut memiliki regulasi tertentu terkait keterlibatan isu lingkungan dalam kegiatan produksi hingga distribusi perusahaan tersebut juga apabila perusahaan tersebut sangat bergantung pada minat konsumen yang tersegmentasi sebagai konsumen produk hijau. Top manager menetapkan komitmennya pada penerapan atau implementasi isu lingkungan sesuai dengan orientasi dan strategi perusahaan sehingga identitas perusahaan tersebut tidak serta merta berubah dari visi misi awal perushaan tersebut. Perusahaan pada umumnya bekerjasama dengan pelaku bisnis lainnya atau dengan NGO untuk menentukan, membentuk dan membenahi etika industri perusahaan tersebut tetapi tetap dengan tujuan yang menguntungkan perusahaan tersebut. Top manager memiliki kekuasaan untuk mempengaruhi perusahaan secara langsung dalam pembentukan kebijakan perusahaan dengan hanya mengakui atau melihat pola stakeholder (yang dalam hal ini konsumen) dalam pasar, kelompok stakeholder yang menonjol dan memiliki legitimasi tersendiri dalam pasar yang memiliki peran tertentu dalam mempengaruhi top manager.

Dalam Lush sendiri posisi top manager dipegang oleh Mark Constantine sebagai CEO dari Lush. Constantine menjelaskan bahwa ia sendiri juga merupakan salah satu dari masyarakat yang memiliki kepedulian terhadap isu lingkungan, sehingga ia sebagai CEO yang memiliki pengaruh besar dalam perusahaan Lush selalu mencoba untuk menyelipkan pesan dan usaha untuk melestarikan lingkungan, seperti pernyataan Constantine yang dikutip penulis dalam artikel yang dimuat dalam (Shepherd 2017) berikut:

"I began unintentionally making naked products and I've gone down that route ever since. My first invention was the shampoo bar in the late eighties. Since then we've taken the concept much further. But in a time when plastic pollution is a growing problem, it makes even more sense to branch out and push the boundaries just a little further" (Shepherd 2017) hal. 2-3 
Dengan didorong nilai yang dipegang oleh Constantine terkait isu lingkungan terutama dalam hal limbah plastik kemasan produk dan juga dari perhatian publik terhadap hal yang sama mendukung terciptanya inovasi naked product yang merupakan jawaban dari persoalan isu tersebut. Constantine menetapkan kebijakan perusahaan Lush untuk meminimalisir penggunaan kemasan untuk pemasaran produknya sebagai bentuk respon dari perhatian konsumennya terhadap isu sampah plastik dan juga sebagai implementasi dari pemikiran atau perspektif pribadinya terkait isu lingkungan. Isu sampah plastik yang menjadi salah satu perhatian Constantine tersebut juga merupakan salah satu hal yang menjadi perhatian masyarakat internasional juga konsumen produk Lush, sehingga Constantine meresmikan inovasi naked product pada tahun 2017 sebagai jawaban dari keperdulian dan isu terkait sampah plastik yang beredar dalam masyrakat juga bagi kegiatan produksi serta distribusi Lush Corp tersebut. Dengan pemasaran produk Lush berupa naked product menjadi jawaban dari kegiatan pengurangan penggunaan kemasan plastik dalam kegiatan distribusi produk Lush yang sebelumnya masih menggunakan kemasan plastik yang dapat didaur ulang atau dikembalikan lagi ke toko Lush untuk memasuki tahap daur ulang dan penggunaan kembali dalam perusahaan.

\section{Hasil Kebijakan Lush Corporation}

Setelah melihat poin-poin sebelumnya yang menjadi indikator dari teori stakeholder (perhatian publik, media, top management), Lush mengeluarkan kebijakan baru untuk merespon perhatian konsumen terkait isu environmentalisme terutama isu limbah sampah plastik. Pada dasarnya kebijakan tersebut merupakan pembaharuan dari kebijakan yang sebelumnya telah digunakan oleh Lush, hanya saja dalam hal ini kebijakan tersebut mendapatkan perhatian lebih dari konsumen akibat semakin tingginya kesadaran masyarakat terkait limbah plastik sampah kemasan. Lush muncul sebagai perusahaan produk gaya hidup pertama yang mengimplementasikan kegiatan untuk mengurangi limbah plastik dengan menggunakan metode reduce dari konsep 3R (reduce atau mengurangi, reuse atau menggunakan kembali, recycle atau mendaur ulang) dalam kegiatan distribusi atau marketing perusahaan. Karena pada dasarnya banyak perusahaan yang mengklaim sebagai perusahaan environmental friendly tetapi hanya berfokus pada poin recycle yang seharusnya merupakan poin terakhir dari konsep $3 R$, karena tujuan utama dari konsep $3 R$ tersebut untuk mengurangi konsumsi produk kemasan sehingga limbah yang muncul dari setiap kegiatan konsumsi juga dapat berkurang, kemudian baru muncul upaya untuk menggunakan kembali produk kemasan tersebut apabila kegiatan mengurangi konsumsi tidak dapat dibendung dan yang terakhir pada tahap daur ulang setelah proses penggunaan kembali karena produk kemasan memiliki aturan penggunaan kembali yang berbeda-beda. Lush muncul dengan inovasi naked product yang dapat diartikan sebagai pemasaran 
produk tanpa kemasan dengan tujuan utama untuk mengurangi penggunaan plastik sebagai kemasan produk sehingga dapat memenuhi keinginan konsumen yang mengikuti tren environmentalisme atau konsumen yang hanya ingin ikut serta dalam upaya pengurangan sampah plastik, inovasi tersebut juga membantu Lush Corporation dalam penghematan energi serta bahan baku untuk kegiatan produksi plastik kemasan produk sehingga emisi karbon yang dihasilkan selama kegiatan produksi dapat dikurangi dengan signifikan.

Ide inovasi naked product sendiri pertama kali muncul pada tahun 2006 dengan konsiderasi data 2\% gas rumah kaca serta menggunakan $8 \%$ dari sumber minyak dunia dalam kegiatan produksi kemasan, di Inggris sendiri sebagai negara asal Lush Corp memproduksi 10 juta ton sampah kemasan dan setengah dari itu tidak dapat melalui proses daur ulang dan mencemari lingkungan. Pada tahun 2006 Lush Corp telah menekan produksi kemasan plastik sebesar 3 juta kemasan dengan tidak memberikan kemasan pada produk solid dan memberlakukan kampanye untuk mengembalikan 5 kemasan produk bekas Lush kembali ke Lush Corp untuk di daur ulang oleh perusahaan dan reproduksi kembali untuk menjadi kemasan produk baru. Hingga akhirnya pada tahun 2017 Lush berhasil mengembangkan inovasi naked product dengan memberikan pilihan solid dari setiap produk yang diproduksi oleh Lush Corp sehingga penggunaan kemasan plastik dapat diminimalisir, dan kampanye mengembalikan 5 kemasan produk bekas Lush tetap dijalankan dan konsumen yang mengembalikan kemasan produk tersebut akan diberikan satu produk face mask sebagai rewards. (Constantine 2007). Hingga akhirnya inovasi naked product mendapatkan respon yang positif baik dari konsumen, NGOs berbasis lingkungan, terhitung hingga tahun 2017 70\% dari seluruh produk Lush tersedia dengan variasi produk solid sehingga dapat didistribusikan tanpa menggunakan kemasan. Lush sendiri menyediakan pilihan untuk menyimpan naked product tersebut dalam tin atau kaleng kemasan yang lebih ramah lingkungan dan dapat digunakan berulang kali lebih baik daripada kemasan plastik (Shepherd 2017).

\section{SIMPULAN}

Tren environmentalisme yang muncul dalam masyarakat akibat pengaruh dari organisasi, komunitas, aktivis hingga media yang mengangkat isu lingkungan sebagai salah satu isu global yang layak untuk diperhatikan memberikan banyak perubahan dalam tatanan masyarakat, salah satunya dalam kegiatan ekonomi. Dengan semakin meluasnya pengaruh tren environmentalisme hingga menjadi salah satu isu yang diperhatikan oleh banyak publik global juga mendukung terjadinya perubahan dalam MNCs atau perusahaan

multinasional untuk ikut mengikuti alur yang terjadi dalam masyarakat. Karena pada dasarnya MNCs 
mengikuti dan memperhatikan alur dan perubahan dalam pasar yang terjadi akibat perubahan dalam masyarakat sehingga permintaan akan produk juga ikut berubah dengan tujuan yang sudah pasti agar tidak kehilangan peluang keuntungan.

Dalam paper ini penulis telah menganalisis bagaimana tren environmentalisme dapat mempengaruhi pengambilan kebijakan oleh Lush Corporation menggunakan stakeholder theory yang terbagi menjadi beberapa indikator yaitu perhatian publik, media dan top management. Dalam indikator perhatian publik ditemukan bahwa Lush merupakan perusahaan yang mengikuti perubahan dalam masyarakat dengan memperhatikan perhatian publik akan isu lingkungan terutama dalam isu limbah plastik. Kemudian dalam indikator media, Lush menggunakan berbagai macam media untuk mengetahui bagaimana perhatian publik terkait isu lingkungan dan bagaimana respon konsumen Lush terhadap inovasi yang dilakukan oleh Lush sebagai respon dari perhatian publik yang muncul. Lush menggunakan media komunikasi langsung dengan konsumen sehingga terdapat feedback yang transparan dari konsumen terhadap inovasi produk hingga etika bisnis Lush Corporation itu sendiri serta penulis memaparkan data kepuasan konsumen Lush sebagai data pendukung bahwa komunikasi antara konsumen dengan Lush merupakan data yang valid dan dapat dikatakan sebagai faktor yang mempengaruhi perusahaan. Dalam indikator top management, penulis menemukan bahwa pada dasarnya CEO dari Lush Corporation sendiri telah memiliki nilai-nilai environmentalist sehingga perusahaan secara tidak langsung mendapatkan pengaruh dari cara pandang CEO tersebut terkait isu lingkungan, tetapi CEO Lush Corporation sendiri juga tetap memperhatikan bagaimana perhatian atau arah pasar Lush terhadap isu environmentalisme tersebut.

Inovasi dari Lush Corporation sebagai respon dari tren environmentalisme yang muncul dalam masyarakat adalah naked product yang merupakan respon Lush terkait isu limbah plastik yang semakin disadari oleh masyarakat luas termasuk konsumen Lush itu sendiri. Sehingga dapat dilihat bahwa tren environmentalisme tersebut dapat mempengaruhi kegiatan produksi hingga distribusi dari MNCs karena pada dasarnya MNCs sangat bergantung dengan pasar yang terdiri dari konsumen (dalam hal ini adalah masyarakat atau publik). Dalam studi kasus yang diangkat oleh penulis, yaitu Lush Corporation memang terlihat sangat pasti bahwa isu lingkungan mempengaruhi Lush tersebut karena pada dasarnya perusahaan tersebut menerapkan atau mengimplementasikan kegiatan produksi dan distribusi hijau (atau memperhatikan lingkungan). Tetapi jika dianalisis lebih lanjut tren yang muncul dalam masyarakat akan selalu mempengaruhi MNCs, hal tersebut dapat dibuktikan dengan stakeholder theory yang menganalisis bagaimana perhatian publik (yang dapat dipengaruhi oleh tren yang muncul dalam masyarakat) dapat mencapai perusahaan sehingga dapat mempengaruhi kebijakan yang diambil oleh perusahaan tersebut. 


\section{DAFTAR PUSTAKA}

Ajami, R.A. and Goddard, G.J. (2006). International business: Theory and practice. ME Sharpe.

Baker, S. K. (2006). Sustainable Development. New York: Routledge.

Banerjee, S. B., Iyer, E. S., \& Kashyap, R. K. (2003). Corporate Environmentalism: Antecedents and Influence of Industry Type. Journal of Marketing 67(2), 106-122.

Constantine, M. (2007). Lush. P.2. Lush UK. https://uk.lush.com/article/go-naked (diakses 03 Mei 2020).

Elliott, R. (2013). "The taste for green: The possibilities and dynamics of status differentiation through "green" consumption." Poetics 41(3), 294-322.

Freeman, R.E., Harrison, J.S., Wicks, A.C., Parmar, B.L. and De Colle, S. (2015) Stakeholder Theory As an Ethical Approach to Effective Management: applying the theory to multiple contexts. Review of Business Management. Review of Business Management, 858-869.

Himmelberger, J. J., \& Brown, H. S. (1995). Global corporate environmentalism: Theoretical expectations and empirical experience. Business Strategy and the Environment, 2-7.

Hirsh, J. B., \& Dolderman, D. (2007). Personality predictors of Consumerism and Environmentalism: A preliminary study. Personality and Individual Difference, 2-5.

Klossner, D. (2012). Organizational Consciousness: Factors that Influence Environmentalism on MNCs in India. Academy of Management Proceedings, 1-6.

Lang, J. C., \& Ho, A. C. (2007). Environmentalism and the multinational corporation: viewpoint-part II. Journal of Environmental Studies, 3-12.

Loeb, Walter. "Lush Beauty." Taking The Industry By Storm Thanks To Young Love, 7 April 2017: 1-3.

Lush. (2016). LUSH UK. Lush UK. https://uk.lush.com/article/charity-pot-funding-guidelines (diakses 29 April 2020).

Poggenpohl, Sanrine van Odijk \& Anne. (2019) Going Plastic Free. 4 Zero Waste Strategies for Businesses, 2.

Rhodes, J., Bergstrom, B., Lok, P. and Cheng, V. (2014). A framework for stakeholder engagement and sustainable development in MNCs. Journal of Global Responsibility, 82-103.

Sabanoglu, Tugba. 28 Agustus 2020. "Turnover of Lush Cosmetics Limited Worldwide 2012-2019." Statista. https://www.statista.com/statistics/892361/turnover-lush-cosmetics-limited-worldwide/ (diakses 29 April 2020)

Shepherd, Amy. (20 November 2017). The Naked Truth. Packaging-Free Cosmetics, p. 1-3.

Skins, Richard. (14 September 2010). LUSH. Lush UK. http://uk.lush.com/article/our-environmental-policy (diakses May 3, 2020).

Sustainbalilitydegree. (1 Juli 2014). The 14 Most Influential Sustainability NGOs, 1-3. 